\title{
KRONIK
}

\section{Seniorarbejdslivet skal være både bedre og længere}

\author{
Harald Børsting
}

Vores velfærdssamfund drives af, at dem, der kan, bidrager. I takt med at vi lever længere, og det generelle sundhedsniveau løbende er blevet forbedret, er det glædeligt, at danskerne i stigende grad vælger at tage nogle ekstra år på arbejdsmarkedet.

Alligevel kan vi se, at de 60-64 årige i mindre grad arbejder end den øvrige befolkning. Samtidig peger flere studier på, at mange gerne vil arbejde så længe som muligt. Derfor nedsatte den daværende regering i maj 2018 Seniortænketanken til at komme med anbefalinger til, hvordan kvaliteten i seniorarbejdslivet kan forbedres, så vi kan give flere seniorer, der kan og vil, lyst til og mulighed for at blive længere på arbejdsmarkedet.

$\mathrm{Nu}$ har vi i tænketanken afsluttet arbejdet og kommer derfor med anbefalinger til regeringen. I denne kronik vil jeg komme ind på de udfordringer, der har været udgangspunktet for Seniortænketankens arbejde, samt de virkemidler, vi i tænketanken vurderer kan hjælpe flere til at blive længere på arbejdsmarkedet.

\section{Det uudnyttede potentiale skal bringes i spil}

I løbet af de næste 20 år forventes aldersgruppen over 65 år at vokse med godt 400.000 personer. Det er der grund til at glæde sig over. Gennemsnitsalderen stiger, og flere oplever at have et godt helbred i deres seniortilværelse. Samtidig har vi oplevet mindre ungdomsårgange siden efterkrigstiden. Det betyder, at mange vil forlade arbejdsmarkedet, hvis vi fastholder tidligere normer for tilbagetrækning - mens færre træder ind på arbejdsmarkedet.

Tal fra vores nabolande - Sverige og Norge - bekræfter, at der i Danmark er et uudnyttet potentiale, vi sammen kan være bedre til at bringe i spil. Andelen af seniorer i aldersgruppen 55-64 år, som fortsætter med at arbejde, er i Sverige $77,9 \%$ og $72 \%$ i Norge - i Danmark er den $70,7 \%$. Hvis Danmark kunne komme op på det svenske niveau, ville det svare til at øge beskæftigelsen med omkring 50.000 personer.

Måden, hvorpå vores arbejdsmarked i dag er skruet sammen, er på mange måder produktet af en kultur, der tilsiger, at der er et forudbestemt tidspunkt, hvor "det vist også er på tide at trække sig tilbage." Engang var man i slutningen af sit arbejdsliv, når man havde rundet de 50 år. I dag har man mere end 15 år tilbage på arbejdsmarkedet frem til folkepensionsalderen. Det peger på et behov for at opdatere vores normer og vores begreb om, hvornår man er senior.

Hvornår er man så senior? Det er et vanskeligt spørgsmål at besvare, da det at føle 
sig ældre er individuelt. Jeg mener ikke, at det er meningsfuldt at kalde personer under 60 år for seniorer. Flere og flere seniorer vil i de kommende år kunne fortsætte meget længere på arbejdsmarkedet. Og her er det centralt, at de oplever de rette rammer og muligheder for et meningsfuldt seniorarbejdsliv mellem et godt og langt arbejdsliv og pensionstilværelsen.

\section{Arbejdspladsbesøg og analyser}

I løbet af det sidste års tid har vi i Seniortænketanken besøgt flere arbejdspladser, bl.a. et slagteri og en kommune med fokus på fastholdelse inden for sociale forhold, beskæftigelse, sundhed og omsorg. Her er vi blevet præsenteret for erfaringer fra både ledere, HR-medarbejdere, seniormedarbejdere og deres kolleger. Vi har samtidig i vores arbejde inddraget den nyeste viden på området og fået gennemført en række analyser.

Samlet set er det vores vurdering, at der er behov for et større fokus på at understøtte den enkeltes mulighed for at blive ved med at være en aktiv del af arbejdsmarkedet. Blikket skal altså vendes mod lokale og fleksible løsninger. Det kræver de rigtige rammer det gælder både centralt hos aftaleparterne og samfundsmæssigt, ved at der bl.a. er tilstrækkelige muligheder for opkvalificering og sporskifte, og ved at arbejdsmiljøet er i orden.

\section{Fleksible løsninger til gavn for den enkelte}

Det er Seniortænketankens langsigtede målsætning, at andelen af seniorer i aldersgruppen 60-70 år, der er i job, år for år skal nærme sig gennemsnittet for resten af arbejdsmarkedet. Anbefalingerne har tre overordnede sigtelinjer.

Første sigtelinje: Der skal etableres bedre muligheder og vilkår for det gode og lange arbejdsliv. Vores anbefalinger er rettet mod en bred vifte af aktører, der tæller bl.a. arbejdsmarkedets parter, ledere, kolleger og seniorerne selv ude på arbejdspladserne, pensionsselskaberne, jobcentrene, a-kasserne og det politiske system.

Vi anbefaler konkret, at aftaleparterne på det private og offentlige område bliver mere opmærksomme på, at rammer og aftaler udstikker den rigtige retning for fastholdelsen af seniorer. Parterne har et ansvar for aktivt at fremme brugen af redskaber, som bidrager til at fastholde seniorer lokalt.

Et andet sted at tage fat er på vores AMU-uddannelser, hvor realkompetencevurderinger lige nu er rettet mod optag på uddannelser. Vi anbefaler, at der igangsættes en udvikling af kompetenceafklaringen i systemet rettet mod konkrete jobfunktioner. Det vil gøre det muligt for den beskæftigede at få hjælp til et sporskifte for $\mathrm{fx}$ at undgå nedslidning eller prøve nye udfordringer og for den ledige og jobcentret at målrette den aktive indsats.

Udgangspunktet for et langt og godt arbejdsliv er et godt helbred. Men nogle arbejdspladser kan have svært ved at komme i gang med og fastholde det forebyggende arbejde. Vi anbefaler derfor, at der igangsættes et pilotforsøg med en indsats bestående af dialog og håndholdt arbejdsmiljøvejledning i en afgrænset målgruppe af virksomheder inden for udsatte brancher.

\section{Styrket indsats overfor ledige og øget gennemskuelighed}

Sigtelinje to: Ledige seniorer skal hurtigt hjælpes tilbage i job. Seniorer er ikke mere ledige end resten af befolkningen, men er længere tid ledige end andre aldersgrupper og har også større risiko for at blive langtidsledige.

Derfor anbefaler vi, at jobcentre og a-kasser med tidlige samtaler samt ordinær jobformidling hjælper den enkelte senior hurtigst muligt $\mathrm{i}$ job. Det skal både tjene til den åbenlyse 
fordel, at senioren bibeholder sin tilknytning til arbejdsmarkedet. Men det skal også hjælpe med at afdække, om den enkelte senior har særlige udfordringer, der gør, at der er forøget risiko for langtidsledighed og derfor behov for andre indsatser og tilbud.

Tredje sigtelinje: De økonomiske incitamenter for at udskyde pensionsalderen er styrket i de seneste år. Tilsvarende er desværre også systemets kompleksitet. Det kan være uoverskueligt for den enkelte at sætte sig ind i reglerne omkring tilbagetrækningsvalget.

Vi lægger derfor vægt på, at seniorer får mere hjælp, bedre overblik og dermed bedre grundlag for at træffe beslutningen om, hvornår de vil trække sig tilbage fra arbejdsmarkedet. Konkret anbefaler vi bl.a. at se på mulighederne, for at "pensionsinfo.dk" gøres mere dynamisk, så det er muligt at lave prognoser for udbetalingerne ved forskellige scenarier for opsparing og pensionering. Derudover foreslår vi også, at den kommende kommission, der skal se på differentieret folkepensionsalder, også ser på en generel forenkling af pensionsreglerne.

\section{Løbende fokus på fremskridt}

Der er grund til at tro på, at hvis vi kan ændre kulturen og styrke fastholdelsesindsatsen på arbejdspladserne, så vil flere have lyst til og mulighed for at tage et par ekstra år på arbejdsmarkedet. For at kunne følge udviklingen, foreslås det at etablere et partnerskab mellem regeringen og de centrale aktører på området, som samarbejder om, at beskæftigelsen for seniorer fortsat stiger.

Partnerskabets aktører skal årligt følge op på, hvilke skridt der skal tages for at understøtte, at sigtelinjerne og dermed den langsigtede målsætning realiseres.

Seniortænketanken håber med disse anbefalinger at skubbe på udviklingen, så flere seniorarbejdsliv bliver både bedre og længere. Så mere arbejdsglæde forløses og mere arbejdspotentiale bringes i spil. Til værdi for den enkelte, arbejdspladserne og vores fælles samfund.

Harald Børsting, formand for Seniortænketanken

e-mail: haraldborsting@gmail.com 